\title{
Faktor-faktor yang mempengaruh Kinerja Guru SMK Negeri di Kabupaten Aceh Utara.
}

\author{
Oleh \\ Andi Safrizal, Apridar,Marbawi \\ PROGRAM PASCASARJANA ILMU MANAJEMEN \\ FAKULTAS EKONOMI DAN BISNIS \\ UNIVERSITAS MALIKUSSALEH
}

\begin{abstract}
ABSTRAK
This study aims to analyze the influence of the factors that affect the performanceofState Vocational School teachers in North Aceh Regency. Work ability factors, compensation for teacher performance and organizational culture, work motivation and review the mediating effects of organizational culture variables, work motivation. The data used in this study were 156 public vocational school teachers in North Aceh Regency. The data analysis method used is structural analysis with Structural Equation Modeling using the Amos Version 20 program. The results showed that the variable work ability, compensation significantly influence teacher performance as well as organizational culture variables, work motivation mediates the three exogenous variables (work ability, compensation and organizational culture, work motivation) with endogenous variables (teacher performance) partially. The recommendation that can be given is that leaders need to foster an attitude of loyalty towards the institution so that teachers have commitment, motivation and cultural values to be able to improve work for their performance.
\end{abstract}

Keywords: Work ability, Compensation, Organizational culture, Work Motivation, Teacher Performance.

\section{PENDAHULUAN}

\section{Latar Belakang Masalah}

Keberhasilan suatu organisasi dalam mencapai tujuan sangat dipengaruhi oleh sumber daya manusia yang terdapat dalam organisasi tersebut, yang merupakan pengerak dari berbagai sumber daya didalam suatu organisasi. Memahami pentingnya sumber daya manusia, organisasi perlu melakukan pengelolaan dan pemberdayaan agar produktivitas dan kinerja organisasi semakin meningkat. Perkembangan ilmu pengetahuan dan teknologi yang cepat telah membawa perubahan global dalam segala bidang dan aspek kehidupan. Salah satu perubahan global adalah terjadinya 
revolusi kemampuan kerja yang ditandai oleh ketatnya persaingan untuk bertahan dan berbenah diri mengikuti perubahan yang sangat cepat. Sejalan dengan perubahan global, dunia pendidikan pun telah diwarnai oleh persaingan antar sekolah dalam meningkatkan mutu hasil pendidikan. Guru merupakan merupakan tenaga pendidik dan ujung tombak dalam memenangkan persaingan tersebut. Sebagai bagian dari sistem pendidikan Nasional sekolah menengah kejuruan merupakan pendidikan menengah yang mempersiapkan peserta didik terutama untik bekerja dalam bidang tertentu, dapat beradaptasi dilingkungan kerja, dapat melihat peluang kerja dan dapat mengembangkan diri di kemudian hari. Tujuan sekolah menengah kejuruan (SMK) tersebut direalisasikan dalam sruktur kurukulum yang memuat tiga program yaitu Normatif,adaptif,dan produktif. Keberhasilan guru dalam kegiatan belajar mengajar di tentukan oleh kinerja guru, sebagai tenaga pendidik. Jika kinerja guru baik maka hasil proses belajar mengajar akan baik pula,sehingga berdampak secara signifikan terhadap mutu lulusan yang dihasilkan dalam sebuah instansi pendidikan. Kinerja guru penting dalam mencapai tujuan pembelajaran yang optimal. Kinerja (performance) adalah keluaran yang dihasilkan oleh fungsi-fungsi atau individu-individu pada suatu pekerjaan atau suatu profesi tertentu. Kinerja yang sering juga disebut sebagai prestasi kerja adalah hasil kerja secara kuantitas dan kualitas yang dicapai seseorang dalam melaksanakan tugas sesuai tanggung jawab yang diberikan pada waktu tertentu. Kinerja merupakan gambaran pencapaian pelaksanaan suatu kegiatan/program/kebijaksanaan dalam mewujudkan sasaran, tujuan, misi, visi organisasi (Bastian 2014). Selanjutnya Dipdiknas (2004: 11) menyatakan kinerja guru adalah kemampuan guru untuk mendemostrasikan berbagai kecakapan dan kopetensi yang dimilikinya. Esensi dari kinerja guru tidak lain merupakan kemampuan guru dalam menunjukkan kecakapan atau kopetensi yang dimilikinya dalam dunia kerja yang sebenarnya.

"Budaya Organisasi sistem makna, nilai-nilai dan kepercayaan yang dianut bersama dalam suatu organisasi yang menjadi rujukan untuk bertindak dan membedakan organisasi satu dengan organisasi lain (Mas'ud, 2004). Budaya organisasi selanjutnya menjadi identitas atau karakter utama organisasi yang dipelihara dan dipertahankan (Mas'ud, 2004). Karyawan ( Guru) yang budaya organisasi yang memadai akan dapat menyelesaikan pekerjaan dengan baik sesui dengan waktu dan target yang telah ditetapkan dalam program kerja.Hal ini terjadi karna karyawan dapat mencurahkan seluruh kemampuannya dalm melaksanakan tugas yang menjadi tanggung jawabnya ( Kreiner dan Kinicki 2003:185). Kemampuan pegawai dalam melaksanakan tugasnya merupakan wujud dari pengetahuan dan ketrampilan yang dimiliki.

Motivasi kerja berasal dari kata “ movere” yang berarti dorongan atau menggerakkan. Motivasi (motivation) dalam manajemen hanya di tunjukkan pada sumber daya manusia umumnya dan kemampuan pada khususnya. Motivasi adalah keinginan dalam diri seseorang yang menyebabkan orang tersebut bertindak (Mathis dan jeckson,2006:114). Pada dasarnya ada 3 karakteristik pokok Andi Safrizal, Apridar, Marbawi 
motivasi,yaitu (1) usaha, (2) kemauan yng kuat,(3) arah dan tujuan.Maksud dari masing-masing karakteristik dapat diringkas sebagai berikut: a.Usaha b.Kemauan keras c. Arah dan tujuan .Motivasi bukanlah yang dapat diamati tetapi hal yang dapat disimpulkan adanya suatu prilaku yang tampak (Supardi dan Anwar,2004). Motivasi yang menyebabkan guru bersemangat dalam mengajar Karena kebutuhan yang diharapkan guru terpenuhi.

Faktor lain yang mempengaruhi kemampuan dan kinerja adalah kekuatan fisik,ketrampilan, yang mendorong semangat yang ada didalam maupun diluar dirinya baik itu yang berupa reward maupun fanishment sehingga Herberg dan Luthans (2003) menyatakan bahwa pada manusia terdapat enam faktor pemuas: 1) prestasi kerja yang diraih (achivement), 2) Pengakuan orang lain (recognition), tanggung jawab (responsibility), 4) peluang untuk maju (advancement), 5) kepuasan kerja itu sendiri (the workitself), 6) dan pengembangan karir ( the possibility of growth). Sedangkan faktor kemampuan kerja meliput: 1) Kecekatan, 2) Kekuatan fisik 3) ketrampilan, 4) Pendidikan, 5) Pelatihan, Mutu dari supervise tekhnis dari hubungan antara kemampuan , pendapatan.

Selanjutnya kompensasi merupakan salah satu faktor yang mempengaruhi produktivitas kerja pendapat tersebut diperkuat oleh Racmawati (2018) mengatakan kopensasi diberikan dengantujuan memberikan rangsangan kepada tenaga kerja untuk meningkatkan prestasi kerja efesiensi dan efektivitas produktivitas kerja. Apabila kompensasi di terapkan dengan baik akan menciptakan motivasi. Menurut Mangkunegara (2009) Motivasi adalah kondisi yang mampu menggerakkan egawai agar mampu mencapai tujuan dari motivnya. Salusu (2000) mengatakan seorang bersedia melakukakan pekerjaan karna dirangasang oleh motivasi. Jadi motivasi adalah faktor penting sebagai penggerak produktivitas karyawan salah satunya didapat dari penerapan kompensasi yang baik. menurut Ludi Wishnu Wardana (2008) Motivasi kerja merupakan daya penorong yang menyebabkan seseorang bertingkah laku,memberi arah dan mengatur tingkah laku serta menentukan tingkah laku pada suatu tujuan tertentu. Hal ini dapat dipahami bahwa suatu prilaku seseorang yang disertai oleh adanya motivasi yang tinggi, dihapkan akan menghasilkan kerja yang memuaskan. Sebagai guru mereka membawa keinginan-keinginan dan kebutuhan yang perlu mendapat pemenuhan. Hal ini menceminkan dari kebutuhan untuk mendapatkan kebutuhan yang layak seperti makan,tempat tinggal dan pakaian yang dapat dipenuhi dengan gaji yang diterima,kebutuhan keamanan dan keselamatan kerja,keinginan untuk dihormati,adanya pengakuan,serta kebutuhan untuk menunjukkan kemampuan,keahlian dan potensi diri. Berdasarkan pengamatan awal yang dilakukan oleh peneliti pada SMK di Kabupaten Aceh Utara ditemukan beberapa fenomena diantaranya masih ada guru yang belum sertifikasi. Dengan adanya sertifikasi diharapkan guru berusaha untuk meningkatkan kopetensi yang harus dimiliki. Kopetensi yang harus dimiliki guru kopetensi pedagogis,kopetensi kepribadian,kopetensi profesional,kopetensi sosial Kopetensi guru dipengaruhi oleh banyak faktor. Diantaranya kemampuan kerja,kompensasi,budaya 
organisasi dan moyivasi kerja diantara modal untuk mencapai tujuan pendidikan adalah penguasaan kopetensi yang memedai. Bedasarkan pengamatan yang penulis lakukan fenomena guru yang belum mengikuti diklat sertifikasi di SMK Negeri dikabupaten aceh utara bisa dilihat pada tabel :

\section{Jumlah guru sertifikasi}

\begin{tabular}{llcc}
\hline NO & \multicolumn{1}{c}{ Nama Sekolah } & $\begin{array}{c}\text { Guru } \\
\text { sertifikasi }\end{array}$ & Jumlah Guru \\
\hline 1 & SMK N 1 Lhoksikon & 32 orang & 74 Orang \\
2 & SMK N 1 Tanah luas & 17 orang & 38 Orang \\
3 & SMK N 1 Syamtaliara Aron & 4 orang & 8 Orang \\
4 & SMK N 1 Dewantara & 28 orang & 36 Orang \\
\hline & Jumlah & 81 orang & 156 Orang \\
\hline
\end{tabular}

Sumber : UPTD PPMG Wilayah III

Dinas Pendidikan Aceh 2019

\section{Rumusan Masalah}

Berdasarkan latar belakang yang telah diuraikan sebelumnya, maka dapat dirumuskan permasalahan penelitian sebagai berikut:

1. Bagaimanakah pengaruh kemampuan kerja dan budaya organisasi terhadap kinerja guru pada SMK di Kabupaten Aceh Utara.

2. Bagaimanakah pengaruh kompensasi terhadap motivasi kerja pada SMK di Kabupaten Aceh Utara.

3. Bagaimanakah pengaruh motivasi kerja terhadap kinerja guru terhadap kinerja guru SMK Negeri di Kabupaten Aceh Utara.

4. Bagaimanakah pengaruh budaya organisasi terhadap kinerja guru SMK Negeri di Kabupaten Aceh Utara.

5. Bagaimanakah pengaruh kemampuan kerja terhadap kerja guru SMK Negeri diKabupaten Aceh Utara.

6. Bagaimanakah pengaruh kompensasi terhadap kinerja guru SMK Negeri di kabupaten Aceh Utara.

7. Apakah budaya organisasi memediasi hubungan Kemampuan kerja terhadap kinerja guru SMK Negeri di Kabupaten Aceh Utara.

8. Apakah Motivasi kerja memediasi hubungan antara kompensasi terhadap kinerja guru SMK Negari di Kabupaten Aceh Utara. 


\section{Tujuan Penelitian}

Penelitian ini bertujuan untuk mendapatkan bukti-bukti empiris yang berkaitan dengan pengaruh antara kemampuan kerja dan kompensasi terhadap budaya organisasi dan motivasi kerja untuk meningkatkan kinerja guru SMK di Kabupaten Aceh Utara seperti:

1. Untuk menguji dan menganalisis pengaruh kemampuan kerja dan budaya organisasi pada SMK Negeri di Kabupaten Aceh Utara.

2. Untuk menguji dan menganalisis pengaruh kompensasi terhadap motivasi kerja pada SMK Negeri di Kabupaten Aceh Utara.

3. Untuk menguji dan menganalisis pengaruh Motivasi terhadap kinerja guru SMK Negeri di Kabupaten Aceh Utara.

4. Untuk menguji dan menganalisis pengaruh budaya organisasi terhadap kinerja guru SMK Negeri di Kabupaten Aceh Utara.

5. Untuk menguji dan menganalisis pengaruh kemampuan kerja terhadap kinerja guru SMK Negeri di Kabupaten Aceh Utara.

6. Untuk menguji dan menganalisis pengaruh kompensasi terhadap kinerja guru SMK Negeri di Kabupaten Aceh Utara.

7. Untuk menguji dan menganalisis budaya organisasi memediasi hubungan antara Kemampuan kerja terhadap kinerja guru SMK di Kabupaten Aceh Utara.

8. Untuk menguji dan menganalisis motivasi kerja memediasi hubungan antara kompensasi terhadap kinerja guru SMK Negeri di Kabupaten Aceh Utara.

\section{Manfaat Penelitian}

Penelitian ini memiliki beberapa manfaat antara lain sebagai sumbangan penting dan memperluas wawasan bagi kajiaan ilmu manajemen sumber daya manusia, Hasil penelitian ini dapat digunakan sebagai tolak ukur dalam mengukur pencapaian kinerja guru SMK Negeri di Kabupaten Aceh Utara.

1. Sebagai sumbangan penting dan memperluas wawasan bagi kajian ilmu manajemen sumberdaya manusia sehingga dapat dijadikan rujukan untuk pengembangan penelitian berikutnya.

2. Memberikan sumbangan penting dan memperluas kajian ilmu manajemen yang menyangkut kinerja guru.

3. Menambah konsep baru bagi pengembangan ilmu manajemen.

4. Hasil penelitian ini bisa menjadi bahan masukan bagi pihak pengambil keputusan untuk meningkatkan kinerja guru SMK Negeri di Kabupaten Aceh Utara.

5. Hasil penelitian ini dapat digunakan sebagai tolak ukur dalam mengukur pencapaian kinerja guru SMK Negeri di Kabupaten Aceh Utara 


\section{METODOLOGI PENELITIAN}

\section{Objek dan Lokasi Penelitian}

Objek penelitian merupakan sumber diperolehnya data yang digunakan dalam penelitian. Untuk lebih jelas mengenai objek dan lokasi penelitian dapat dilihat pada Tabel berikut ini :

\begin{tabular}{clc}
\hline No & \multicolumn{1}{c}{ Nama Sekolah } & Alamat \\
\hline 1. & SMK N. 1 lhoksukon & Lhoksukon \\
\hline 2. & SMK N.1 Tanah luas & Tanah luas \\
\hline 3. & SMK N.1 Syamtalira Aron & Syamtalira Aron \\
\hline 4. & SMK.N. 1 Dewantra & Dewantara \\
\hline
\end{tabular}

Sumber : UPTD PPMG Wilayah III

Dinas Pendidikan Aceh 2019

Penelitian dimulai dari bulan November sampai dengan bulan Februari 2020. Peneliti memilih objek penelitian seperti yang ada di Tabel dengan pertimbangan bahwa keempat sekolah tersebut merupakan SMK Negeri yang ada di Kabupaten Aceh Utara. Sehingga dapat menjadi representatif dari kemampuan kerja, kompensasi, budaya organisasi, motivasi kerja dan kinerja guru SMK Negeri di Kabupaten Aceh Utara.

\section{Populasi dan Sampel}

Populasi adalah sebuah kumpulan dari semua kemungkinan orang-orang, benda-benda, dan ukuran lain dari objek yang menjadi perhatian dalam suatu penelitian, suatu bagian dari populasi tertentu yang menjadi perhatian dalam sebuah penelitian.

\section{Populasi}

Populasi adalah sebuah kumpulan dari semua kemungkinan orang-orang, benda-benda, dan ukuran lain dari objek yang menjadi perhatian (Suharyadi \& Purwanto, 2013). Populasi dalam penelitian ini adalah seluruh guru SMK di Kabupaten Aceh Utara yang berjumlah 156 orang. Untuk lebih jelas mengenai populasi dalam penelitian ini dapat diuraikan dalam Tabel berikut:

Jumlah Populasi

\begin{tabular}{llc}
\hline NO & \multicolumn{1}{c}{ Nama Sekolah } & Jumlah Guru \\
\hline 1 & SMK N 1 Lhoksikon & 74 Orang \\
2 & SMK N 1Tanah luas & 38 Orang \\
3 & SMK N 1 Syamtaliara Aron & 8 Orang \\
4 & SMK N 1 Dewantara & 36 Orang \\
\hline & Jumlah & 156 orang \\
\hline
\end{tabular}

Sumber: UPTD PPMG Wilayah III

Dinas Pendidikan Aceh 2019 


\section{Sampel}

Untuk mempermudah suatu penelitian, pada umumnya dalam penelitian kuantitatif akan menggunakan sampel sebagai data primernya. Sampel adalah suatu bagian dari populasi tertentu yang menjadi perhatian (Suharyadi \& Purwanto, 2013). Untuk penentuan jumlah sampel dalam penelitian ini juga mempertimbangkan model penelitian yang digunakan. Model penelitian yang digunakan dalam penelitian ini adalah model Structural Equation Modelling(SEM), dimana dalam SEM jumlah sampel yang ideal antara 100-200 (Hair et al., 2009) dan juga harus mempertimbangkan jumlah indikator yang ada dalam model.Hair et al. (2009) lebih lanjut mengatakan untuk penentuan jumlah sampel dapat berjumlah 5-10 dari jumlah indikator. Dalam penelitian ini terdapat 26 indikator sehingga jumlah sampel bisa berkisar antara 130 -260 responden. Jumlah sampel ditentukan dengan mengalikan jumlah indikator dengan 5, sehingga total sampel sebanyak $28 \times 5=140$ responden. Untuk berjaga-jaga terjadinya data yang outlier maka ditambahkan lagi dengan 16 responden. Sehingga jumlah sampel sebanyak 156 orang responden, jumlah populasi tersebut dijadikan sampel.

\section{Pengukuran variabel/ Instrumen}

Metode pengumpulan data yang digunakan dalam penelitian ini yaitu dengan menggunakan instrumen kuesioner, yaitu sekumpulan pertanyaan tertulis untuk mendapatkan informasi dari responden. Dalam kuesioner penelitian ini terdapat dua jenis pernyataan/pertanyaan yaitu: (1) pernyataan yang berkaitan dengan pengukuran variabel penelitian; (2) pertanyaan yang berkaitan dengan data kemampuan kerja,kompensasi dan kinerja guru. Pada penelitian ini konstruk budaya organisasi dan motivasi kerja sebagai variabel intervening antara variabel eksogen.

Dalam penelitian ini, teknik pengumpulan data dilakukan dengan menggunakan metode kuesioner. Hadi (2006) menyatakan bahwa kuisioner adalah set pertanyaan yang sudah disiapkan dan ditulis sebelumnya oleh peneliti, untuk

dimintakan jawabannya pada responden, kuisioner tidak selalu berupa pertanyaan, namun juga dapat berupa pernyataan. Teknik pengumpulan data dilakukan dengan memberikan daftar pertanyaan atau kuesioner secara langsung kepada 140 responden yang merupakan guru SMK di Kabupaten Aceh 
Utara yang dibuat dengan menggunakan skala 1-5 (likert) untuk mendapatkan data yang bersifat interval dan diberi nilai atau skor, untuk kategori pernyataan dengan jawaban sangat tidak setuju dengan nilai 1 (satu) sampai dengan sangat setuju dengan nilai 5 (lima).

Instrumen Skala Likert

\begin{tabular}{c|l|c|}
\hline No & \multicolumn{1}{|c|}{ Skala Likert } & Skor \\
\hline 1. & Sangat Setuju & 5 \\
2. & Setuju & 4 \\
3. & Netral & 3 \\
4. & Tidak Setuju & 2 \\
5. & Sangat Tidak Setuju & 1 \\
\hline
\end{tabular}

Sumber : Sugiyono (2011)

\section{Deskriptif Jawaban Responden Variabel Kemampuan Kerja}

Hasil analisis deskriptif statistik jawaban responden variabel kemampuan kerja adalah mengenai jawaban tentang item-item variabel kemampuan kerja,berdasarkan Tabel 5.1 dapat dijelaskan bahwa nilai minimum1, nilai maksimum adalah 5 dan dengan nilai range 4 serta nilai ratarata mean 3.400. apabila dihubungkan dengan skala yang ditentukan dalam penelitian ini yaitu: (1) sangat tidak setuju, (2) tidak setuju, (3) netral, (4) setuju. (5) sangat setuju,maka kategori jawaban responden secara rata-rata berada pada skala (4) atau pada kondisi setuju artinya secara umum responden berpendapat setuju terhadap pertanyaan dalam kuisioner mengenai variabel kemampuan $\operatorname{kerja}\left(\mathrm{X}_{1}\right)$.

\section{Deskriptif Jawaban Responden Variabel Kompensasi}

Deskriptif statistik jawaban responden variabel kompensasi adalah mengenai jawaban tentang item-item variabel kepemimpinan. Berdasarkan tabel dapat dijelaskan bahwa nilai minimum 1, nilai maksimum adalah 5 dan nilai rata-rata mean 3.592,maka kategori jawaban responden secara rata-rata berada pada skala (4) atau pada kondisi setuju artinya secara umum responden berpendapat setuju terhadap pertanyaan dalam kuisioner mengenai variabel kompensasi $\left(\mathrm{X}_{2}\right)$.

\section{Deskriptif Jawaban Responden Variabel Budaya Organisasi $\left(\mathbf{Y}_{1}\right)$}


Deskriptif statistik jawaban responden variabel budaya organisasi adalah mengenai jawaban tentang item-item variabel komitmen organisasi,berdasarkan tabel dapat dijelaskan bahwa nilai minimum 1, nilai maksimum adalah 5 dan dengan nilai rata-rata mean 3.430, maka kategori jawaban responden secara rata-rata berada pada skala (4) atau pada kondisi setuju artinya secara umum responden berpendapat setuju terhadap pertanyaan dalam kuisioner mengenai variabel budaya organisasi $\left(\mathrm{Y}_{1}\right)$.

\section{Deskriptif Jawaban Responden Variabel Motivasi Kerja $\left(\mathbf{Y}_{2}\right)$}

Deskriptif statistik jawaban responden variabel motivasi kerja adalah mengenai jawaban tentang item-item variabel kepuasan kerja,berdasarkan Tabel dapat dijelaskan bahwa nilai minimum 1, nilai maksimum adalah 5 dan dengan nilai rata-rata mean 3.518,maka kategori jawaban responden secara rata-rata berada pada skala (3) atau pada kondisi netral artinya secara umum responden berpendapat netral terhadap pertanyaan dalam kuisioner mengenai variabel motivasi kerja $\left(\mathrm{Y}_{2}\right)$.

\section{Deskriptif Jawaban Responden Variabel Kinerja Guru $\left(\mathbf{Y}_{3}\right)$}

Deskriptif statistik jawaban responden variabel kinerja guru adalah mengenai jawaban tentang item-item variabel kepuasan kerja,berdasarkan Tabel dapat dijelaskan bahwa nilai minimum 1, nilai maksimum adalah 5 dan dengan nilai rata-rata mean 3.372,maka kategori jawaban responden secara rata-rata berada pada skala (3) atau pada kondisi netral artinya secara umum responden berpendapat netral terhadap pertanyaan dalam kuisioner mengenai variabel kinerja guru $\left(\mathrm{Y}_{3}\right)$.

\section{A. Analisis Konfirmatori Faktor Kontruk Eksogen}

Adapun uji CFA kontruk eksogen yang terdiri dari kemampuan kerja $\left(\mathrm{X}_{1}\right)$ dan kompensasi $\left(\mathrm{X}_{2}\right)$ dapat dijelaskan pada Gambar berikut : 


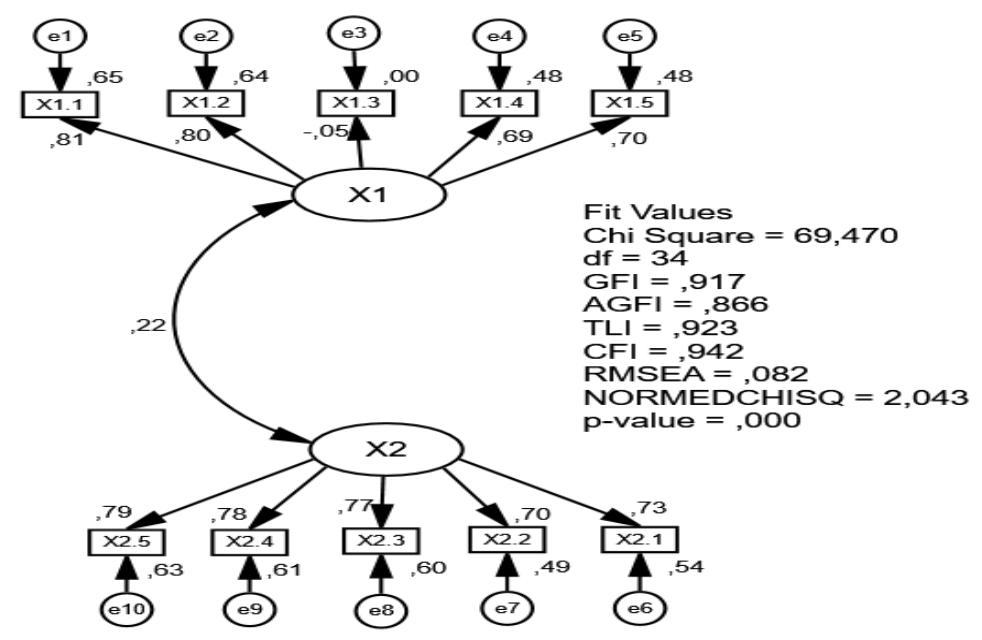

Analisis Konfirmatori Kontruk Eksogen

Sumber : Ouput Amos, 2020

Berdasarkan Gambar dapat disimpulkan bahwa nilai loading factor indikator kemampuan kerja dan kompensasi masih terdapat loading factor $<0.50$ yaitu indicator $\mathrm{X} 1,3$ sehingga masih indicator tersebut harus di keluarkan dari model (Ghozali, 2014), untuk lebih jelasnya dapat dilihat pada tabel berikut ini :

\section{B. Analisis Konfirmatori Faktor Kontruk Endogen}

Adapun uji CFA kontruk endogen yang terdiri dari budaya organisasi $\left(\mathrm{Y}_{1}\right)$, motivasi kerja $\left(\mathrm{Y}_{2}\right)$ dan kinerja guru $\left(\mathrm{Y}_{3}\right)$ dapat dilihat pada Gambar berikut :

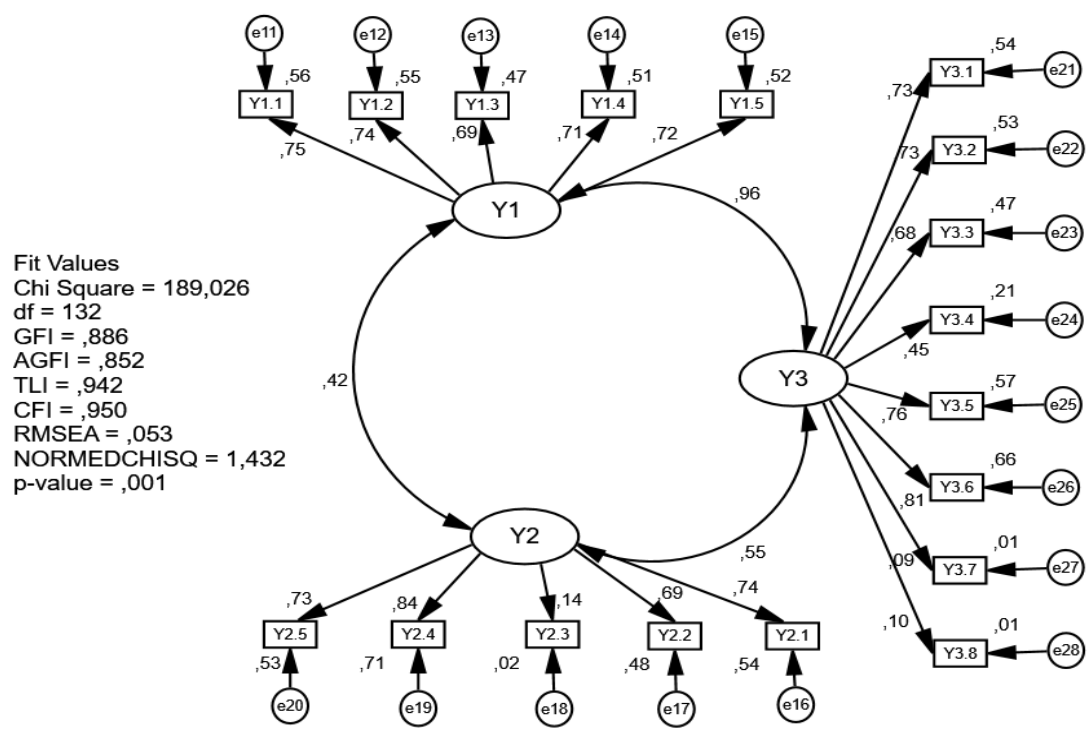

Analisis Konfirmatori Kontruk Endogen

Sumber : Ouput Amos, 2020 
Berdasarkan Gambar dapat disimpulkan bahwa nilai loading factor indikator kontruk endogen masih terdapat loading factor $<0.50$ yaitu indicator $\mathrm{Y} 2.3, \mathrm{Y} 3.4, \mathrm{Y} 3.7$ dan $\mathrm{Y} 3.8$ sehingga indicator tersebut harus di keluarkan dari model, untuk lebih jelasnya dapat dilihat pada Tabel berikut ini :

Pada Gambar dan Tabel dibawah ini disampaikan bahwa nilai loading factor indikator kontruk endogen semuanya berada $>0.50$ untuk lebih jelasnya dapat dilihat pada Gambar berikut ini

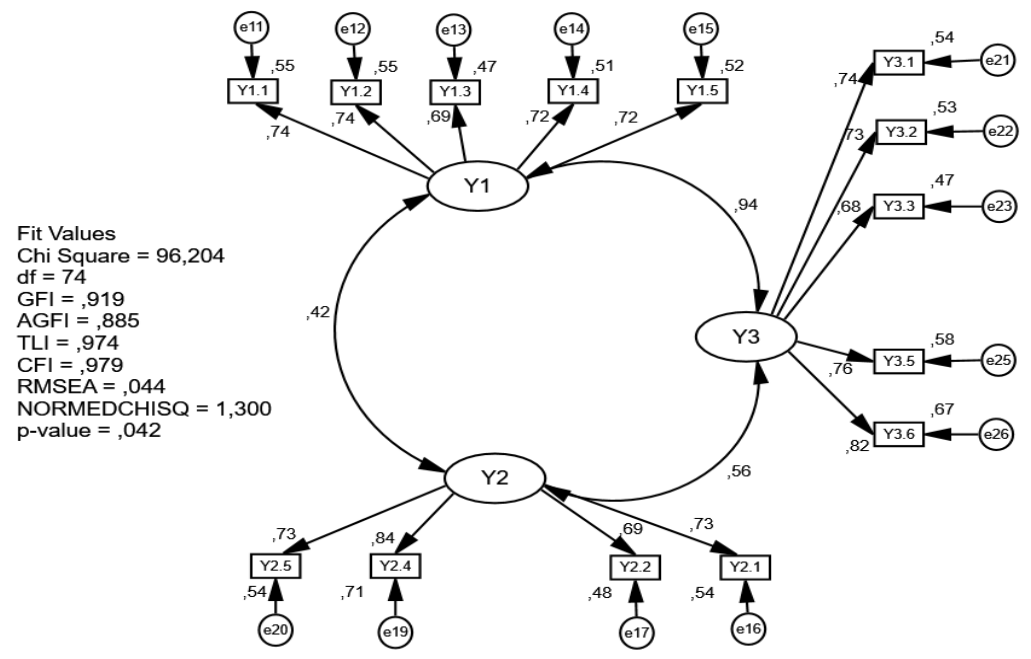

\section{Hasil Uji Reliabilitas Konstruk}

Sebagaimana telah dijelaskan dalam bab 4, reliabilitas konstruk adalah ukuran konsistensi internal dari indikator-indikator konstruk yang menunjukkan derajat sampai mana masing-masing indikator mengindentifikasikan sebuah konstruk yang umum, uji reliabilitas dilakukan dengan 3 cara yaitu construct reliability (CR), average extracted (AVE/VE), dan discriminant validity (DV). Dalam penelitian ini dilakukan perhitungan sekaligus terhadap CR, AVE/VE, dan DV, hasil perhitungan tersebut ditampilkan secara berurutan dibawah ini :

\section{A. Variabel Kemampuan Kerja $\left(\mathbf{X}_{1}\right)$}


Berdasarkan data yang ditunjukan dalam Tabel dapat dijelaskan bahwa variabel kemampuan kerja memiliki nilai CR sebesar 0,836 yang jauh lebih besar dari 0,70 dengan demikian dapat disimpulkan bahwa kemampuan kerja memiliki nilai reliabitas yang sangat baik, sementara itu nilai VE diperoleh sebesar 0,562 yang lebih besar dari 0,50 yang dipersyaratkan, dengan demikian dapat disimpulkan bahwa variabel kemampuan kerja memiliki nilai convergent(berbagi proporsi varian yang tinggi) dan baik,sementara analisis nilai discriminant validity akan diintepretasi secara sekaligus untuk semua variabel dibagian bab berikut ini.

\section{B. Variabel Kompensasi $\left(\mathbf{X}_{2}\right)$}

Berdasarkan data yang ditunjukan dalam Tabel dapat dijelaskan bahwa variabel kempensasi memiliki nilai CR sebesar 0,870 yang jauh lebih besar dari 0,70 dengan demikian dapat disimpulkan bahwa kompensasi memiliki nilai reliabitas yang sangat baik,sementara itu nilai VE diperoleh sebesar 0,572 yang lebih besardari 0,50 yang dipersyaratkan, dengan demikian dapat disimpulkan bahwa kompensasi memiliki nilai convergent(berbagi proporsi varian yang tinggi) yang baik,sementara nilai discriminant validity akan diintepretasi secara sekaligus untuk semua variabel pada bagian bab berikut ini

\section{Variabel Budaya Organisasi $\left(\mathbf{Y}_{1}\right)$}

Berdasarkan data yang ditunjukan dalam Tabel dapat dijelaskan bahwa variabel budaya organisasi memiliki nilai CR sebesar 0,845 yang jauh lebih besar dari 0,70 dengan demikian dapat disimpulkan bahwa variabel budaya organisasi memiliki nilai reliabitas yang sangat baik,sementara itu nilai VE diperoleh sebesar 0,572 yang lebih besar dari 0,50 yang dipersyaratkan, dengan demikian dapat disimpulkan bahwa variabel kompensasi memiliki nilai convergent(berbagi proporsi varian yang tinggi) yang baik, sementara analisis nilai discriminant validity akan diintepretasi secara sekaligus untuk semua variabel pada bagian lain bab ini.

\section{Variabel Motivasi Kerja $\left(\mathbf{Y}_{2}\right)$}

Berdasarkan data yang ditunjukan dalam Tabel dapat dijelaskan bahwa variabel motivasi kerja memiliki nilai CR sebesar 0,839 yang jauh lebih besar dari 0,70 dengan demikian dapat 
disimpulkan bahwa variabel motivasi kerja memiliki nilai reliabitas yang sangat baik,sementara itu nilai VE diperoleh sebesar 0,567 yang lebih besar dari 0,50 yang dipersyaratkan, dengan demikian dapat disimpulkan bahwa variabel motivasi kerja memiliki nilai convergent(berbagi proporsi varian yang tinggi) yang baik sementara analisis nilai discriminant validity akan diintepretasi secara sekaligus untuk semua variabel pada bagian lain bab ini.

\section{E. Variabel Kinerja Guru $\left(\mathbf{Y}_{3}\right)$}

Berdasarkan data yang ditunjukan dalam Tabel dapat dijelaskan bahwa variabel kinerja guru memiliki nilai CR sebesar 0,863 yang jauh lebih besar dari 0,70 dengan demikian dapat disimpulkan bahwa variabel kinerja guru memiliki nilai reliabitas yang sangat baik,sementara itu nilai VE diperoleh sebesar 0,559 yang lebih besar dari 0,50 yang dipersyaratkan, dengan demikian dapat disimpulkan bahwa variabel kinerja guru memiliki nilai convergent(berbagi proporsi varian yang tinggi) yang baik sementara analisis nilai discriminant validity akan diintepretasi secara sekaligus untuk semua variabel pada bagian lain bab ini.

\section{F. Analisis Discriminant Validity}

Discriminan Valididy untuk mengukur sampai seberapa jauh suatu kontruk benar-benar berbeda dari kontruk lainnya, nilai discriminant validity yang tinggi memberikan bukti bahwa suatu kontruk adalah unit mampu menangkap fenomena yang diukur pada kontruk penelitian, berikut ini analisisnya dapat dijelaskan dibawah ini. 


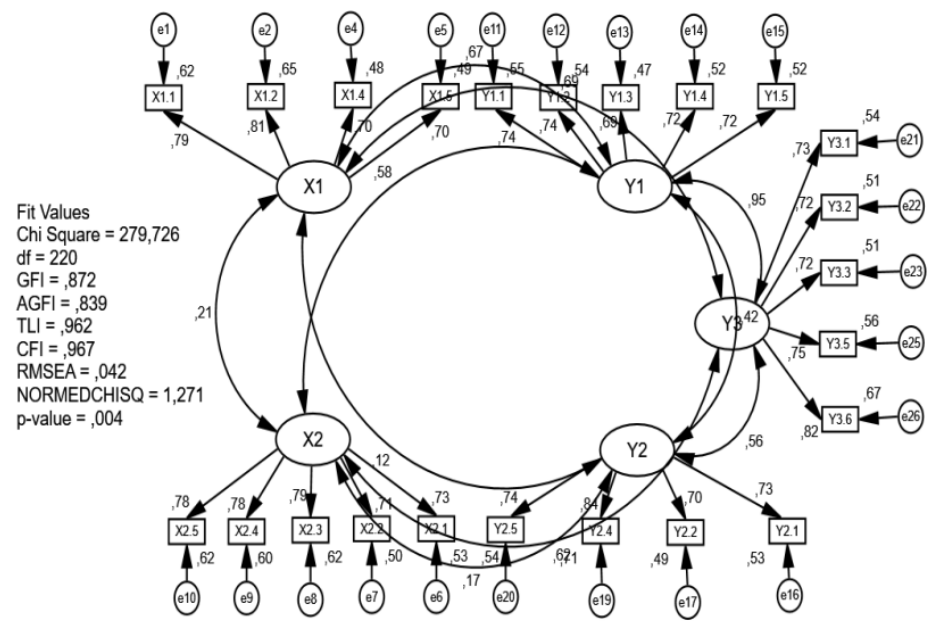

\section{Uji Discrimaninant Validity}

Sumber : Ouput Amos, 2020

Berikut ini pada Tabel merupakan hasil uji Discrinant Validity untuk menihat hubungan korelasi antar variabel laten sebagai berikut.

\section{Uji Multikolinieritas dan Singularitas Data}

Uji Multikoliniritas dalam penelitian ini menggunakan nilai determinant of sample covariance matrix untuk melihat ada tidaknya model memiliki multikolinieritas, menurut Ghozali (2014) nilai determinant of sample covariance matrix yang menjauh dari 0 adalah menunjukkan tidak terdapat multikolinieritas antar variabel.

Hasil Uji Multikolinieritas Melalui Determinant of sample covariance matrix

\begin{tabular}{|c|c|c|c|c|c|c|c|c|c|c|c|c|c|c|c|c|c|c|c|}
\hline \multicolumn{20}{|c|}{ Sample Covariances (Group number 1) } \\
\hline & KT1 & KO6 & $\mathrm{KT} 2$ & KK1 & KT3 & KT4 & KK2 & KO5 & KT5 & $\mathrm{KO3}$ & $\mathrm{KO2}$ & KD1 & KK5 & KK4 & KK3 & $\mathrm{K} 15$ & $\mathrm{~K} / 4$ & $\mathrm{~K} 12$ & K11 \\
\hline KT1 & 1,132 & & & & & & & & & & & & & & & & & & \\
\hline $\mathrm{K} D 6$ & 0,381 & 1,329 & & & & & & & & & & & & & & & & & \\
\hline KT2 & 0,629 & 0,43 & 1,229 & & & & & & & & & & & & & & & & \\
\hline KK1 & 0,362 & 0,574 & 0.297 & 0.944 & & & & & & & & & & & & & & & \\
\hline $\mathrm{KT} 3$ & 0,507 & 0,365 & 0.511 & 0,25 & 0.858 & & & & & & & & & & & & & & \\
\hline KT4 & 0,59 & 0,371 & 0,599 & 0,259 & 0,552 & 1,197 & & & & & & & & & & & & & \\
\hline KK2 & 0,339 & 0,509 & 0,297 & 0,541 & 0,209 & 0.274 & 0,925 & & & & & & & & & & & & \\
\hline KO5 & 0,38 & 0,782 & 0.39 & 0,509 & 0,306 & 0,253 & 0,503 & 1,183 & & & & & & & & & & & \\
\hline KT5 & 0,6 & 0,307 & 0,65 & 0,332 & 0,535 & 0,637 & 0,317 & 0,392 & 1,069 & & & & & & & & & & \\
\hline $\mathrm{KO}$ & 0.424 & 0,709 & 0.478 & 0,45 & 0,356 & 0,408 & 0,479 & 0,578 & 0.417 & 1,133 & & & & & & & & & \\
\hline $\mathrm{KO2}$ & 0.457 & 0,67 & 0,363 & 0,509 & 0,301 & 0.374 & 0,441 & 0,662 & 0.435 & 0,523 & 1,139 & & & & & & & & \\
\hline $\mathrm{k} 01$ & 0,388 & 0.69 & 0,387 & 0,553 & 0,31 & 0,333 & 0,493 & 0.614 & 0.331 & 0,533 & 0,599 & 1,039 & & & & & & & \\
\hline KK5 & 0,397 & 0,656 & 0,321 & 0,468 & 0,309 & 0,294 & 0,535 & 0.479 & 0,291 & 0,574 & 0,562 & 0,571 & 1,132 & & & & & & \\
\hline KK4 & 0.41 & 0,568 & 0,344 & 0.494 & 0,332 & 0,363 & 0,507 & 0,526 & 0.441 & 0,538 & 0.488 & 0.523 & 0,635 & 1,183 & & & & & \\
\hline KK3 & 0,362 & 0,543 & 0,236 & 0,474 & 0,24 & 0,211 & 0,463 & 0,509 & 0,308 & 0,473 & 0,582 & 0,511 & 0,632 & 0,71 & 1,212 & & & & \\
\hline KI5 & 0,253 & 0,499 & 0.21 & 0,438 & 0,195 & 0,22 & 0,299 & 0,542 & 0,27 & 0,492 & 0,497 & 0.522 & 0,338 & 0,422 & 0,394 & 1,142 & & & \\
\hline $\mathrm{KI} / 4$ & 0,19 & 0.421 & 0,2 & 0,485 & 0,115 & 0,167 & 0,362 & 0.442 & 0,149 & 0,493 & 0,314 & 0,48 & 0,391 & 0,362 & 0.43 & 0,689 & 1,413 & & \\
\hline $\mathrm{KI} 2$ & 0,309 & 0,476 & 0,163 & 0.4 & 0,03 & 0.07 & 0,317 & 0,462 & 0,103 & 0,476 & 0.401 & 0,464 & 0,518 & 0,375 & 0,399 & 0,578 & 0,725 & 1,249 & \\
\hline KI1 & 0.287 & 0,462 & 0,09 & 0.426 & 0,191 & 0,125 & 0,355 & 0,503 & 0,149 & 0,431 & 0,379 & 0,422 & 0,362 & 0.437 & 0,411 & 0,571 & 0,667 & 0,816 & 1,16 \\
\hline \multicolumn{20}{|c|}{ Condition number $=38,072$} \\
\hline \multicolumn{20}{|c|}{ Eigenvalues } \\
\hline \multicolumn{20}{|c|}{$8,9192,6561,4351,015,821,797,690,652,641,542,513,468,449,417,399,368,350,302,234$} \\
\hline Determ & nant of & ample c & variance $n$ & aatrix $=$, & & & & & & & & & & & & & & & \\
\hline
\end{tabular}


Berdasarkan hasil uji multikolinieriras seperti pada tabel memperlihatkan nilai Determinant of sample covariancesebesar .001, artinya nilai tersebut mencoba menjauh dari nol, dengan demikian dapat dikatakan bahwa tidak terdapat multikolinieritas antar variabel endogen pada analisis data penelitian ini.

, dapat dijelaskan bahwa semua variabel eksogen berpengaruh signifikan terhadap variabel endogen sehingga model ini sudah dapat untuk menguji hipotesis penelitian.

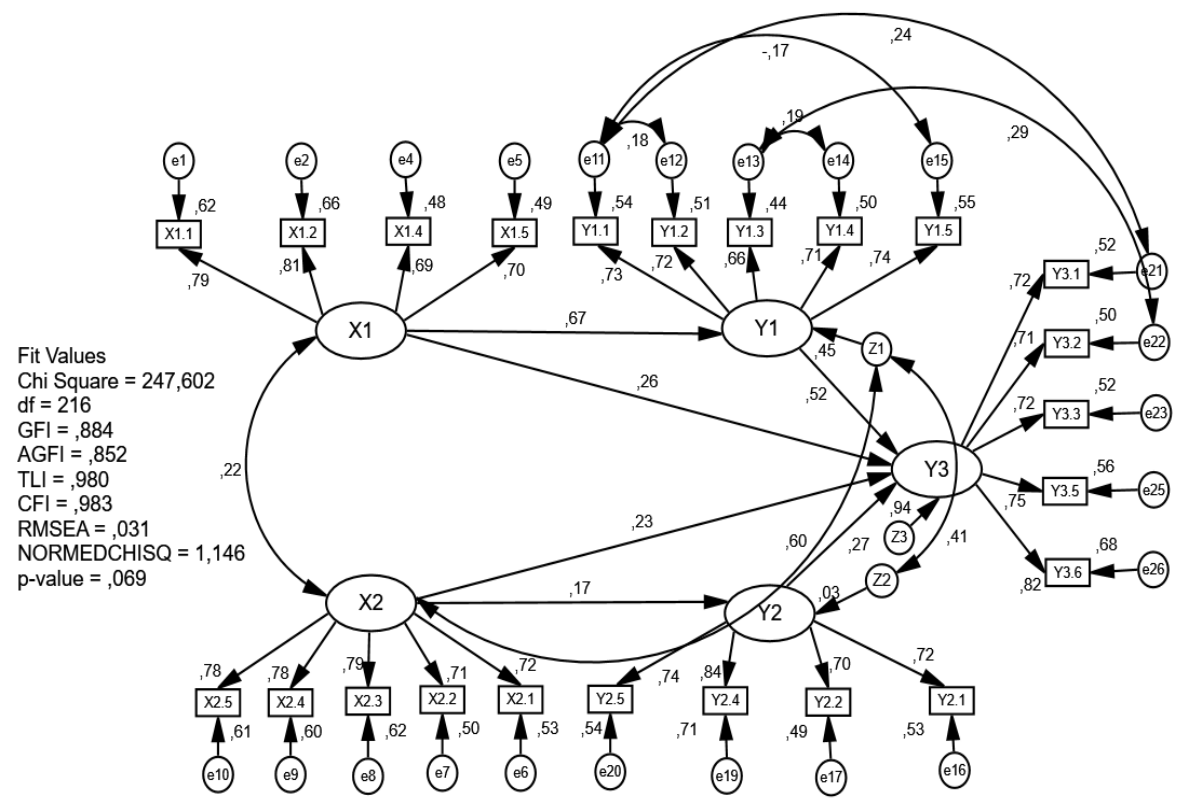

Model Struktural Setelah Modifikasi

Sumber : Ouput Amos, 2020

Hasil Uji Kesesuaian Model Full Model

\begin{tabular}{llcc}
\hline Goodness of Fit Index & Cut-off Value & Hasil Analisis & Evaluasi Model \\
\hline$X^{2}$-Chi-Square & Diharapkan Kecil & 247,602 & Baik \\
Probability & $\geq 0.05$ & 0.069 & Baik \\
GFI & $\geq 0.90$ & 0.884 & Marginal \\
AGFI & $\geq 0.90$ & 0.852 & Marginal \\
CFI & $\geq 0.95$ & 0.983 & Baik \\
TLI & $\geq 0.95$ & 0.980 & Baik \\
CMIN/DF & $\leq 2$ & 1.146 & Baik \\
RMSEA & $\leq 0.08$ & 0.031 & Baik \\
\hline
\end{tabular}

\section{Pengaruh Tidak Langsung (Indirect Effect)}

a. Pengaruh tidak langsung kemampuan kerja terhadap kinerja guru memalui budaya organisasi dilakukan dengan perhitungan Sobel Test An Interactive calculation tool for Mediation tests.

Sesuai dengan Gambar merupakan hasil perhitungan yang diperoleh dari sobel testan interactive calculation tool for mediation tests dimana nilai test statistic diperoleh nilai sebesar 3.345> 2.00. nilai $p$-value sebesar $0,002<0,05$ dan nilai standar error sebesar 0,114 , berdasarkan hasil perhitungan nilai probabilitas untuk jalur c' dengan menggunakan Sobel Test seperti pada Gambar 5.15, maka nilai signifikansi untuk kesemua jalur (A dan B) signifikan sedangkan jalur C 
signifikan sehingga telah memenuhi syarat nudaya organisasi sebagai variable parsial mediasi dengan demikian hipotesis $\mathbf{k e t u j u h}\left(\mathbf{H}_{7}\right)$ diterima, dapat di lihat pada Gambar 5.14 dibawah ini :

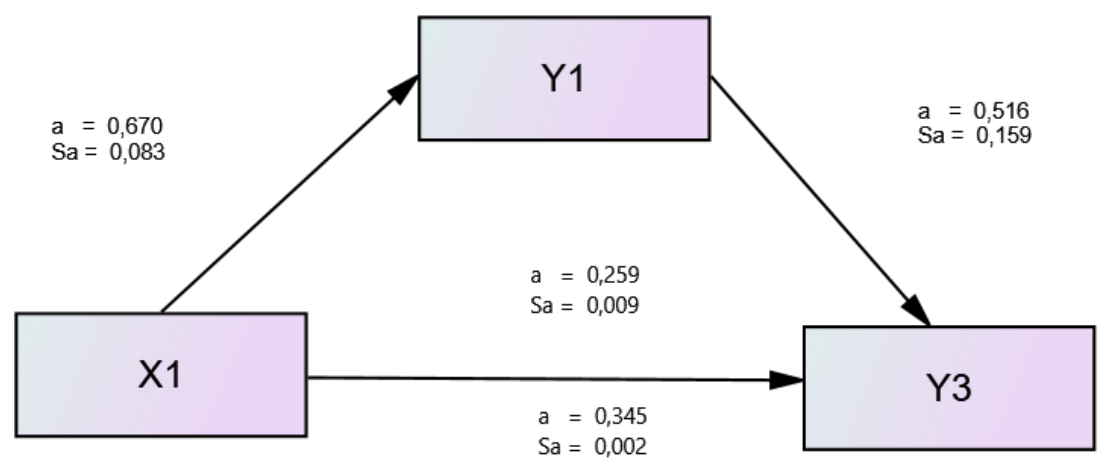

Hasil Uji Efek Mediasi

Gambar atas dapat dijelaskan bahwa koefesien jalur A, jalur B signifikan dan jalur C signifikan, sedangkan jalur $C^{\prime}$ juga signifikan. Karena probabilitas jalur semuasignifikan, sehingga dapat disimpulkan budaya organisasi memenuhi syarat dan berfungsi sebagai variable mediasi secara parsial.

Pengaruh tidak langsung kompensasi terhadap kinerja guru melalui motivasi kerja dilakukan dengan perhitungan Sobel Test An Interactive calculation tool for Mediation tests.

Pengujian Hipotesis Regression Weight Structural Equalition Model

\begin{tabular}{|c|c|c|c|c|c|c|}
\hline No & Pernyataan Hipotesis & Est. & S.E. & C.R. & $P$ & Ket \\
\hline 1 & $\begin{array}{l}\text { Kemampuan kerja berpengaruh positif } \\
\text { dan signifikan terhadap budaya organisasi }\end{array}$ & 0.670 & 0.083 & 6.732 & 0.000 & $\begin{array}{l}\text { Hipotesis } \\
\text { Diterima }\end{array}$ \\
\hline 2 & $\begin{array}{l}\text { Kompensasi berpengaruh positif dan } \\
\text { signifikan terhadap motivasi kerja }\end{array}$ & 0.171 & 0.088 & 1.811 & 0.070 & $\begin{array}{c}\text { Hipotesis } \\
\text { Ditolak }\end{array}$ \\
\hline 3 & $\begin{array}{l}\text { Motivasi kerja berpengaruh positif dan } \\
\text { signifikan terhadap kinerja guru }\end{array}$ & 0.272 & 0.074 & 3.796 & 0.000 & $\begin{array}{r}\text { Hipotesis } \\
\text { Diterima }\end{array}$ \\
\hline 4 & $\begin{array}{l}\text { Budaya organisasiberpengaruh positif dan } \\
\text { signifikan terhadap kinerja guru }\end{array}$ & 0.516 & 0.159 & 3.462 & 0.000 & $\begin{array}{l}\text { Hipotesis } \\
\text { Diterima }\end{array}$ \\
\hline 5 & $\begin{array}{l}\text { Kemampuan kerja berpengaruh positif } \\
\text { dan signifikan terhadap kinerja guru }\end{array}$ & 0.259 & 0.087 & 2.628 & 0.009 & $\begin{array}{l}\text { Hipotesis } \\
\text { Diterima }\end{array}$ \\
\hline 6 & $\begin{array}{l}\text { Kompensasi pengaruh karakteristik } \\
\text { individuterhadap kinerja guru }\end{array}$ & 0.227 & 0.076 & 2.879 & 0.004 & $\begin{array}{r}\text { Hipotesis } \\
\text { Diterima }\end{array}$ \\
\hline 7 & $\begin{array}{l}\text { Budaya organisasi memediasi secara } \\
\text { parsial pengaruh } \\
\text { kerjaterhadap kinerja guru }\end{array}$ & 0.345 & 0.118 & 3.011 & 0.002 & $\begin{array}{l}\text { Hipotesis } \\
\text { Diterima }\end{array}$ \\
\hline 8 & $\begin{array}{l}\text { Motivasi kerjamemediasi secara penuh } \\
\text { pengaruh } \\
\text { guru }\end{array}$ & 0.046 & 0.027 & 1.717 & 0.085 & $\begin{array}{r}\text { Hipotesis } \\
\text { Diterima }\end{array}$ \\
\hline
\end{tabular}


Sesuai hasil pada tabel diatas, terdapat lima pernyataan hipotesis yang menyebutkan berpengaruh signifikan antara variabel eksogen dan variabel endogen dan semua variable eksogen berpengaruh positif dan signifikan terhadap kinerja guru SMK Aceh Utara.

\section{Kesimpulan}

Berdasarkan hasil penelitian serta pembahasan yang telah diuraikan sebelumnya, maka dapat disampaikan beberapa kesimpulan sebagai berikut :

1. Kemampuan kerja berpengaruh positif dan signifikan terhadap budaya organisasi guru SMK Aceh Utara, kondisi ini berarti bahwa semakin baik kemampuan kerja guru dalam mendidik, maka semakin meningkat budaya organisasinya.

2. Kompensasi tidak berpengaruh terhadap motivasi kerja guru SMK Aceh Utara, kondisi ini bahwa kompensasi yang diterima guru SMK aceh Utara belum memberikan motivasi guru dalam mendidik pada SMK Aceh Utara.

3. Motivasi kerja berpengaruh positif dan signifikan terhadap kinerja guru SMK Aceh Utara, kondisi ini berarti bahwa semakin termotivasi dan semangat guru dalam proses pembelajaran, maka semakin meningkat kinerjanya.

4. Budaya organisasi berpengaruh positif dan signifikan terhadap kinerja guru SMK Aceh Utara, kondisi ini berarti bahwa semakin baik nilai-nilai budaya yang dipahami dalam mendidik, maka semakin meningkat kinerja guru dalam mendidik siswa pada SMK Aceh Utara.

5. Kemampuan kerja berpengaruh positif dan signifikan terhadap kinerja guru SMK Aceh Utara, kondisi ini berarti bahwa semakin baik kemampuan kerjaguru dalam mendidik, maka semakin meningkat kinerja guru SMK Aceh Utara.

6. Kompensasi berpengaruh terhadap kinerja guru SMK Aceh Utara, kondisi ini bahwa kompensasi yang diterima guru SMK aceh Utara dapat memberikan dan meningkatkan kinerja guru dalam mendidik pada SMK Aceh Utara. 
7. Budaya organisasi memediasi hubungan kemampuan kerja dengan kinerja guru SMK Aceh Utara, artinya budaya organisasi dapat memediasi secara parsial hubungan kemampuan kerja dan kinerja guru SMK Aceh Utara.

8. Motivasi kerja memediasi hubungan kompensasi dengan kinerja guru SMK Aceh Utara, artinya motivasi kerja dapat memediasi secara penuh hubungan kompensasi dan kinerja guru SMK Aceh Utara.

\section{Saran-Saran}

Dalam rangka meningkatkan kinerja guru SMK Aceh Utara, penulis menyarankan beberapa saran sebagai beikut :

1. Para pimpinan dan kepala sekolah SMK Aceh Utara perlu terus meningkatkan kemampuan kerja, dengan cara pemberian bimbingan dan pelatihan, agar dapat meningkatkan karir dan berdampak pada kinerja guru.

2. Kepala sekolah dalam meningkatkan motivasi kerja perlu diperhatikan pengakuan dan penghargaan kepada guru yang bekerja dengan baik agar peningkatan kinerjanya dapat ditingkatkan, dan akhirnya kinerja organisasi juga meningkat.

3. Pimpinan SMK Aceh Utara perlu menumbuhkan sikap loyalitas terhadap instansi agar para guru memiliki komitmen, motivasi dan memiliki nilai budaya untuk dapat meningkatkan kinerjanya.

\section{DAFTAR REFERENSI}

1. Yudha indra permana, (2015). Kemampuan Kerja, Motivasi dan kompensasi terhadap kinerja karyawan dilingkungan SMK kesehatan bakti indonesia medika ngawi. Jurnal MSDM 137 Vol.2 No.9 Desember 2015, Hal. 137-144. ISSN 2303-1174.

2. Syamsul Hadi Senen Siti soliha (2008). Pengaruh Motivasi Kerja dan Kemampuan Kerja Terhadap Produktivitas Kerja Karyawan Pada PT Saflindo Permata. Jurnal Strategi Vol 7 No.14 September 2008

3. Yuliani Indriani (2006). Faktor-faktor yang mempengaruhi Kinerja Guru Matematika dalam pelaksanaan Kurikulum Berbasis kopetensi (KBK) Pada sekolah Menengah kejuruan Atas Kota Palembang. Jurnal Manajemen dan bisnis Vol 4 No 7 Juni 2006

4. Arep, Ishak \& Tanjung, Hendrik. (2002). Manajemen Sumber Daya Manusia. Penerbit Universitas Trisakti. Jakarta.

5. Arifin, Noor. (2012). Analisis Kualitas Kehidupan Kerja, Kinerja, Dan Kepuasan Kerja Pada CV. Duta Senenan Jepara. Jurnal Economia, Volume 8, Nomor 1, April 2012. 
6. As'ad. Moh.(2003). Sumber Daya Manusia, edisi keempat, Liberty, Yokyakara.

7. Azwar, S. (2012). Metode Penelitian. Yogyakarta : Pustaka Pelajar.

8. Baron, R. M., \& Kenny, D. A. (1986). The moderator-mediator variable and statistical considerations. Journal of Personality and Social Psychology, 51, 1173-1182.

9. Bastian, Indra.(2014). Audit Sektor Publik: Pemeriksaan Pertanggungjawaban Pemerintahan. Edisi ke-3.Salemba Empat, Jakarta.

10. Bernardin, H. Jhon (2007). Human Resources Management. Mc. Graw Hill, Inc, Singapore.

11. Brahmasari, Ida Ayu \& Suprayetno, Agus. (2008). Pengaruh Motivasi Kerja, Kepemimpinan dan Budaya Organisasi Terhadap Kepuasan Kerja Karyawan serta Dampaknya pada Kinerja Perusahaan (Studi kasus pada PT. Pei Hai International Wiratama Indonesia). Jurnal Manajemen Dan Kewirausahaan, Vol.10, No. 2, September 2008: 124-135.

12. Darmawan, Arif dan Putri, Marlinda Aulia. (2017). Pengaruh Gaya Kepemimpinan terhadap Komitmen Organisasi MelaluiKepuasan Kerja Sebagai Variabel Intervening.Akuntabilitas: Jurnal Ilmu Akuntansi Volume 10 (1), April 2017 P-ISSN: 1979858X; E-ISSN: 2461-1190 Page $1-18$.

13. Dhermawan, Anak Agung Ngurah Bagus. Sudibya, I Gde Adnyana \& Utama, I Wayan Mudiartha. (2012). Pengaruh Motivasi, Lingkungan Kerja, Kompetensi, dan Kompensasi Terhadap Kepuasan Kerja dan Kinerja Pegawai di Lingkungan Kantor Dinas Pekerjaan Umum Provinsi Bali. Jurnal Manajemen, Strategi Bisnis, dan Kewirausahaan Vol. 6, 173 No. 2 Agustus 2012.

14. Ferdinand, Augusty. (2006). Structural Equation Modelling dalam Penelitian Manajemen, Aplikasi Model-model Rumit Penelitian untuk Tesis Magister dan Disertasi Doktor, Fakultas Ekonomi, UNDIP.

15. Fitriastuti, Triana. (2013). Pengaruh Kecerdasan Emosional, Komitmen Organisasional Dan Organizational Citizenship Behavior Terhadap Kinerja Karyawan. Fakultas Ekonomi, Universitas Mulawarman, Kalimantan Timur, Indonesia. Jurnal Dinamika Manajemen Vol. 4, No. 2, 2013, pp: 103-114.

16. Ghozali, Imam. (2013). Konsep dan Aplikasi Dengan Progran AMOS 21.0, Cetakan ke 4, Badan Penerbit Universitas Diponegoro, Semarang.

17. Gibson, James L., Jhon M. Ivancevich \& James H. Donnelly Jr. (2000). Organizations. MecGraw-Hill International, Boston.

18. Hakim, Adnan.(215). Effect of Organizational Culture, Organizational Commitment to Perfomance. The International Journal of Engineering and sciences Vol 4(5): 38-40.

19. Hair, J. F. JR., et al. (2009). Multivariate Data Analysis. Seventh Edition. Uper Sadle River. New Jersey. PrenticeHall.

20. Hariandja, Marihot Tua Efendi.(2005). Manajemen Sumber Daya Manusia: Pengadaan, Pengembangan, Pengkompensasian dan Peningkatan Produktivitas Pegawai. Jakarta: Grasindo.

21. Hasibuan, Malayu, SP. (2005). Manajemen Sumber Daya Manusia. Edisi Revisi. Bumi Aksara. Jakarta.

22. Heriyanti, Dewita. (2007). Analisis Pengaruh Budaya Organisasi, Kepuasan Kerja, Dan Gaya Kepemimpinan Terhadap Kinerja Karyawan Dengan Komitmen Organisasional Sebagai Variabel Interverning (Studi PT. PLN (Persero) APJ Semarang). Tesis. Program Studi Magister Manajemen. Program Pasca Sarjana Universitas Diponegoro.

23. Khanifah, Siti Palupiningdyah. (2015) Pengaruh kecerdasan emosional dan Budaya Organisasi pada Kinerja dengan Komitmen Organisasi. Manajemen Analysis Journal Vol 4(3) hal. 203-210.

24. Kosasih, Niki. (2014) . Analisis Pengaruh Budaya Organisasi dan Komitmen Keorganisasian terhadap Kinerja Pegawai. Jurnal Dinamika Manajemen Vol. 2(3): hal.199. 
25. Kusworo, Armanu, Rahayu, Minarti, Sumiati. (2015). Influence of Motivation, Organiational Kultur and Working Environment With Organizational Commitment as Mediator to Educator Perfomance. The International Journal of Social Sciences Vol 35(1): hal.6-10.

26. Kreitner, Robert \& Kinicki, Angelo. (2004). Organizational Behavior. $6^{\text {th }}$ edition. McGraw Hill.

27. Kreitner, Robert dan Kinicki, Angelo. (2005). Perilaku Organisasi. Salemba Empat: Jakarta.

28. Lipu, Andi Tonra. Alam, Syamsu \& Umar, Fauziah. (2013). Kepuasan Kerja, Dukungan Organisasi, Gaya Kepemimpinan, Motivasi Kerja Terhadap Kinerja Karyawan pada PT. Bank Mega. Program Magister Manajemen Fakultas Ekonomi Universitas Hasanuddin.

29. Luthans, F. (2006). Perilaku Organisasi. Yogyakarta: Penerbit Andi.

30. Mahmudi. (2005). Manajemen Kinerja Sektor Publik. Yogyakarta: UPP AMP YKPN.

31. Mangkunegara, Anwar Prabu. (2008). Manajemen Sumber Daya Manusia Perusahaan. PT Remaja Rosdakarya. Bandung.

32. Mas'ud, Fuad. (2004). Survai Diagnosis Organisasional (Konsep dan Aplikasi), Badan Penerbit Universitas Diponegoro.

33. Mathis, Robert L. \& Jackson, John H. (2001). Human Resource Management(Terjemahan). Buku 1. Edisi Kesembilan, Penerbit Salemba Empat. Jakarta.

34. Nafisah, Durrotun. (2005). Analisis Pengaruh Gaya Kepemimpinan Terhadap Kepuasan Kerja, Komitmen Organisasi dan Kinerja Karyawan. Fakultas Ekonomi. Universitas Diponegoro.

35. Pancawati, Sri. (2013). Pengaruh Iklim Organisasi, Motivasi Dan Kompetensi Terhadap Kinerja Pegawai Bagian Pembangunan Pemerintah Kabupaten Kediri. Jurnal OTONOMI, Vol. 13, Nomor 1, Januari 2013.

36. Patulak, Martin Efendi. Thoyib, Armanu. Surachman Setiawan, Margono.(2014). The Role of Organizational Commitment as Mediator of Organizational Cultur and Employes Performance. Journal of Economics and Sustainable Devolopment Vol.4(5): hal 169-172.

37. Prihayanto, Susandi \& Ratnawati, Intan. (2011). Analisis Pengaruh Budaya Organisasi dan Motivasi Terhadap Kinerja Karyawan (Studi pada PT. Telekomunikasi Indonesia Tbk, Regional IV Jawa Tengah-Daerah Istimewa Yogyakarta). Yogyakarta.

38. Putriana, Lies.(2015). The Infact of Organizational Cultur on Jon Satifaction, Organizational Commitment And Job Perfomance. International Journal of Education and Research Vol 3(9) :hal. 108-109.

39. Riani, Asri Laksmi (2011). Budaya Organisasi .Yokyakarta : Graha Ilmu.

40. Robbins, S.P. (2008). Perilaku Organisasi. Jakarta: PT Salemba Empat.

41. Robbins, Stephen P. \& Timothy A. Judge. (2009). Organizational Behavior. Thirteenth Edition. New Jersey: Pearson Prentice Hall.

42. Shahzad, Fakhar Iqbal, Zahid Gulzar, Muhammad.(2013). Impact of Organizational Culture on Employes Job Ferfomance. Journal F Business Studies Quarterly Vol 5(2): hal. 59-63.

43. Sedarmayanti.(2007).Sumber Daya Manusia dan Produktifitas kerja, Bandung, Penerbit Bandar Maju.

44. Setiawan, Edi dan Mardalis.(2015). Pengaruh Gaya Kepemimpinan dan Komitmen Organisasi Terhadap Disiplin Kerja dengan Kepuasan Kerja Sebagai Variabel Intervening. Daya Saing. Jurnal Ekonomi Manajemen Sumber Daya. Vol. 17, No. 2, Desember 2015.

45. Siagian, P, Sondang. (2007). Manajemen Sumber Daya Manusia. Jakarta: Bumi Aksara.

46. Silen, Adhi Prastistha. (2016). Pengaruh Kompetensi dan Pengembangan Karir Terhadap Kepuasan Kerja dengan Komitmen Organisasional Sebagai Variabel Mediasi (Studi Pegawai Politeknik Ilmu Pelayaran (PIP Semarang).Jurnal Bisnis dan Ekonomi (JBE), September 2016, Hal. 174 - 185 Vol. 23, No. 2 ISSN: 1412-3126.

47. Sopiah, (2008). Perilaku Organisasi. Edisi Pertama, Yokyakarta :ANDI 
48. Sugiyono. (2011). Metode Penelitian Kuantitatif Kualitatif dan R \& H. Alfabeta. Bandung.

49. Sutrisno, Edy. (2011). Manajemen Sumber Daya Manusia. Jakarta: Kencana.

50. Taurisa, C.M., \& Ratnawati, I. (2012). Analisis Pengaruh Budaya Organisasi dan Kepuasan Kerja terhadap Komitmen Organisasional dalam Meningkatkan Kinerja Karyawan (Studi pada : PT. Sido Muncul Kaligawe Semarang, Jurnal Bisnis dan Ekonomi (JBE). $19: 2$ 170-187.

51. Torang, Syamsir. (2012). Metode Riset Struktur \& Perilaku Organisasi. Alfabeta, Bandung.

52. Wibowo. (2007).Manajemen Kinerja, PT. Raja Grafindo Persada, Jakarta.

53. Wibowo. (2013). Budaya Organisasi, PT. Raja Grafindo Persada, Jakarta

54. Wirawan. (2009). Evaluasi Kinerja Sumber Daya Manusia. Jakarta: Salemba Empat.

55. Yulk, Gary A.(1989)Manajerial Leadership. A Review of Theory and Research. Journal of Management, Vol ,15, No.2, 251-289

56. Engkay Karweti (2010) Pengaruh kemampuan manajerial kepala sekolah dan faktorfaktor yang mempengaruhi motivasi kerja terhadap kinerja guru SLB dikabupaten Subang. Jurnal penelitian pendidikan Vol 11 No 2 Oktober 2011 